\title{
Water Resources of Red River Parish, Louisiana
}

\section{Introduction}

Information concerning the availability, use, and quality of water in Red River Parish, Louisiana (fig. 1), is critical for proper water-supply management. The purpose of this fact sheet is to present information that can be used by water managers, parish residents, and others for stewardship of this vital resource. In 2014, about 5.76 million gallons per day $(\mathrm{Mgal} / \mathrm{d})$ of water were withdrawn in Red River Parish: about $4.23 \mathrm{Mgal} / \mathrm{d}$ from groundwater sources and $1.54 \mathrm{Mgal} / \mathrm{d}$ from surface-water sources ${ }^{1}$ (table 1). Withdrawals for agricultural use, composed of general irrigation, rice irrigation, and livestock uses, accounted for about 72 percent $(4.15 \mathrm{Mgal} / \mathrm{d})$ of the total water withdrawn (table 2). Other categories of use included public supply (about 18 percent of the total water withdrawn, or $1.03 \mathrm{Mgal} / \mathrm{d}$ ), industry (about 7 percent, or $0.39 \mathrm{Mgal} / \mathrm{d}$ ), and rural domestic (about 4 percent, or $0.20 \mathrm{Mgal} / \mathrm{d}$ ). Water-use data collected at 5-year intervals from 1960 to 2010 and again in 2014 indicated that water withdrawals peaked in 1975 at more than $7.3 \mathrm{Mgal} / \mathrm{d}$ (fig. 2).

${ }^{1}$ Water-withdrawal data are based on estimated or reported site-specific data and aggregated data, which are distributed to sources. For a full description of water-use estimate methodology, see "Data Collection" in Collier and Sargent (2018). Tabulation of numbers in text and tables may result in different totals because of rounding; nonrounded numbers are used for calculation of totals.

\section{Groundwater Resources}

The primary freshwater-bearing aquifers in Red River Parish are the Red River alluvial, Carrizo-Wilcox, and Upland terrace aquifers (figs. 1 and 3). The Dolet Hills and Naborton aquifers are below the Carrizo-Wilcox aquifer, each present in thin lenses within their respective confining units, but few wells are registered in these aquifers, and they provide little freshwater. The altitude of the base of fresh groundwater (water having a chloride concentration of 250 milligrams per liter $[\mathrm{mg} / \mathrm{L}]$ or less) ranges from more than 50 feet (ft) above the National Geodetic Vertical Datum of 1929 (NGVD 29) along the center of the parish in the Red River alluvial aquifer to deeper than $100 \mathrm{ft}$ below NGVD 29 in the northeastern part of the parish in the Carrizo-Wilcox aquifer (Newcome and Page, 1962).

\section{Red River Alluvial Aquifer}

The Red River alluvial aquifer is present in a narrow band in the western half of Red River Parish and is the most heavily pumped aquifer underlying the parish. The aquifer is composed of sediments deposited primarily by the Red River, which generally grade from silt and clay at the surface to coarse sand and gravel at the base. The thickness of the Red River alluvial aquifer averages about $80 \mathrm{ft}$ along the western border and about $40 \mathrm{ft}$ in the eastern part of the parish (Newcome and Page, 1962). The altitude of the base of the aquifer

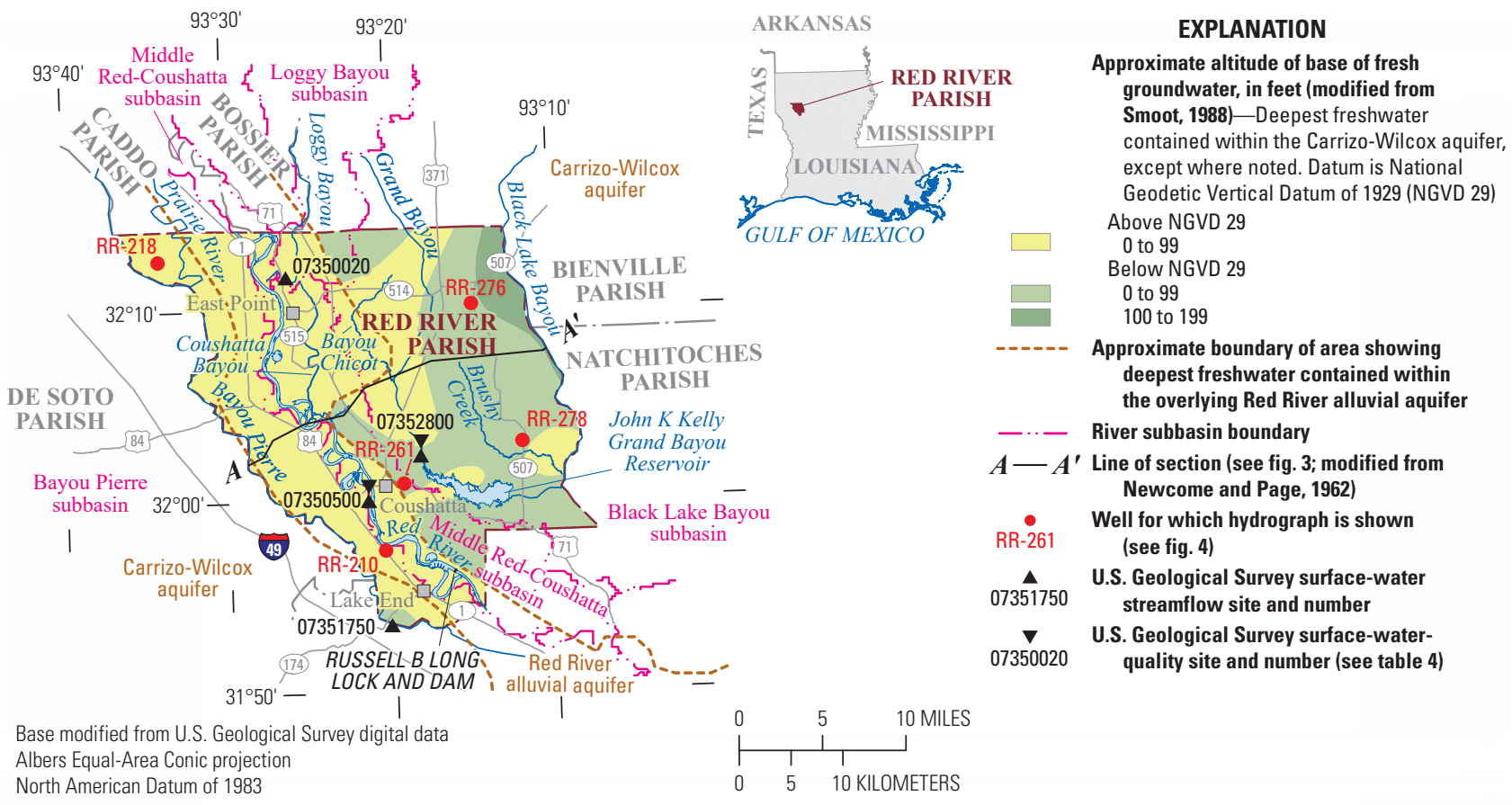

Figure 1. Location of study area, Red River Parish, Louisiana. 
Table 1. Water withdrawals, in million gallons per day, by source in Red River Parish, Louisiana, 2014 (Collier, 2018).

\begin{tabular}{lcc}
\hline \multicolumn{1}{c}{$\begin{array}{c}\text { Aquifer or } \\
\text { surface-water body }\end{array}$} & Groundwater & $\begin{array}{c}\text { Surface } \\
\text { water }\end{array}$ \\
\hline Red River alluvial aquifer & 2.88 & \\
Carrizo-Wilcox aquifer & 0.95 & \\
Upland terrace aquifer & 0.35 & \\
Miscellaneous aquifers & 0.04 & \\
Bayou Pierre & & 0.16 \\
John K. Kelly Grand Bayou Reservoir & & 0.37 \\
Red River & & 0.30 \\
Miscellaneous surface-water bodies & & 0.70 \\
\cline { 2 - 3 } Total & $\mathbf{4 . 2 3}$ & $\mathbf{1 . 5 4}$ \\
\hline
\end{tabular}

Table 2. Water withdrawals, in million gallons per day, by use category in Red River Parish, Louisiana, 2014 (Collier, 2018).

\begin{tabular}{lccc}
\hline \multicolumn{1}{c}{ Use category } & Groundwater & Surface water & Total \\
\hline Public supply & 0.65 & 0.37 & 1.03 \\
Industrial & 0.01 & 0.37 & 0.39 \\
Rural domestic & 0.20 & 0.00 & 0.20 \\
Livestock & 0.04 & 0.06 & 0.11 \\
Rice irrigation & 0.74 & 0.08 & 0.83 \\
General irrigation & 2.57 & 0.64 & 3.21 \\
\cline { 2 - 4 } Total & $\mathbf{4 . 2 3}$ & $\mathbf{1 . 5 4}$ & $\mathbf{5 . 7 6}$ \\
\hline
\end{tabular}

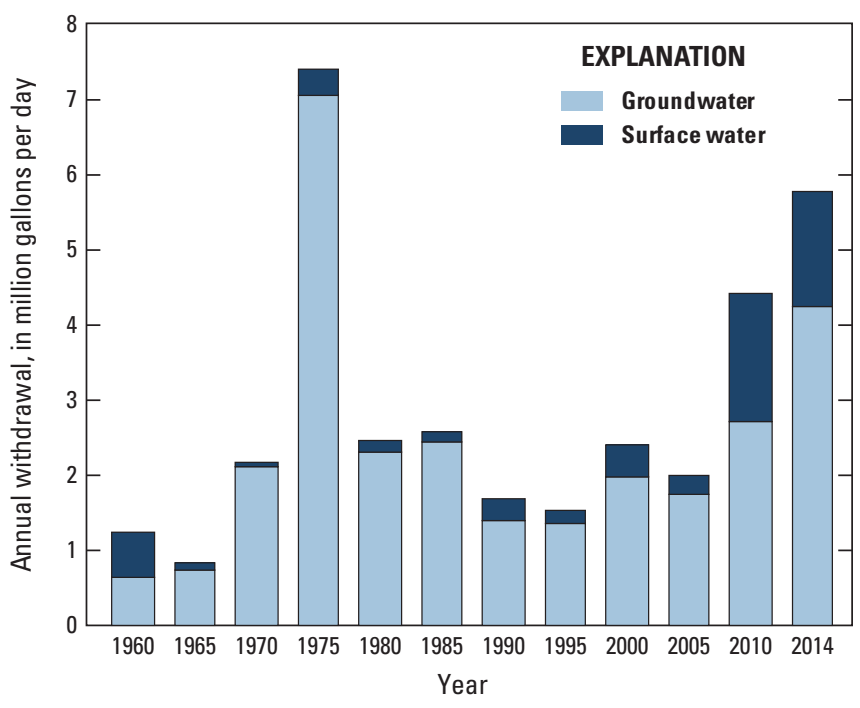

Figure 2. Water withdrawals in Red River Parish, Louisiana, 1960-2014 (U.S. Geological Survey, 2017; Collier, 2018).

is relatively constant throughout its extent at about $50 \mathrm{ft}$ above NGVD 29 (Smoot, 1988).

The primary source of recharge for the Red River alluvial aquifer is the infiltration of precipitation with secondary sources of recharge from leakage from underlying aquifers (Newcome and Page, 1962).
Water levels in wells RR-210 and RR-218 have remained relatively stable throughout their periods of record (fig. 4). Small seasonal fluctuations between 5 and $10 \mathrm{ft}$ generally show the aquifer's response to precipitation and water-level altitude elevation of the Red River. Water levels in RR-210 sharply increased around 1995, which was probably caused by the completion of the Russell B. Long Lock and Dam (also known as Lock and Dam \#4) on the Red River in the southern part of the parish in 1994. Both RR-210 and RR-218 show little, if any, long-term increasing or decreasing trend (fig. 4).

State well-registration records listed 99 active water wells screened in the Red River alluvial aquifer in Red River Parish in 2017: 45 irrigation wells, 40 domestic wells, 6 public supply wells, and 8 industrial wells. Depths of these wells ranged from 17 to 150 gallons per minute (gal/min) (Louisiana Department of Natural Resources, 2017). In 2014, about $2.88 \mathrm{Mgal} / \mathrm{d}$ were withdrawn from the Red River alluvial aquifer, with use categories including $0.02 \mathrm{Mgal} / \mathrm{d}$ for rural domestic, $2.29 \mathrm{Mgal} / \mathrm{d}$ for general irrigation, $0.03 \mathrm{Mgal} / \mathrm{d}$ for livestock, and $0.53 \mathrm{Mgal} / \mathrm{d}$ for rice irrigation (Collier, 2018).

\section{Carrizo-Wilcox Aquifer}

The Carrizo-Wilcox aquifer is composed of sands and gravels of Paleocene and Eocene age in two separate geologic units, the Carrizo Sand and the Wilcox aquifer, which are hydraulically connected and are generally considered to constitute a single aquifer in Red River Parish (Ryals, 1982). The Carrizo-Wilcox aquifer underlies all of Red River Parish, gradually thickening from the west to the east. Saltwater is present in most areas underlying the Red River, whereas freshwater is generally available in areas east of the Red River.

The altitude of the base of fresh groundwater in the aquifer is shallow (usually less than $10 \mathrm{ft}$ deep) in much of the parish, remaining near NGVD 29 in the western part of the parish. Between the center and the eastern side of the parish, the base of freshwater declines sharply from about $50 \mathrm{ft}$ below NGVD 29 to about $200 \mathrm{ft}$ below NGVD 29 (Newcome and Page, 1962; Ryals, 1984). Groundwater generally moves towards the Red River in the center of the parish (Seanor and Smoot, 1995).

In 2013, a study of water-level altitudes in wells screened in the Carrizo-Wilcox aquifer indicated that levels were between 110 and about $170 \mathrm{ft}$ above NGVD 29 from the center to the northeastern corner of Red River Parish (Fendick and Carter, 2015). Water levels at well RR-278, screened in the Carrizo-Wilcox aquifer in Red River Parish, generally fluctuated less than $1 \mathrm{ft}$ annually during its period of record from 1981 to 2016 (fig. 4). The long-term record indicates a gradual increase of about $3 \mathrm{ft}$ during 1981-2000 and then a gradual decrease of about $5 \mathrm{ft}$ thereafter (U.S. Geological Survey [USGS], 2018).

State well-registration records listed 207 active water wells screened in the Carrizo-Wilcox aquifer in Red River Parish in 2017: 151 domestic, 25 public supply, 16 irrigation, and 15 industrial wells. Well depths ranged from 20 to $500 \mathrm{ft}$ below land surface, and reported yields ranged from 5 to $500 \mathrm{gal} / \mathrm{min}$ (Louisiana Department of Natural Resources, 2017). In 2014, about $0.95 \mathrm{Mgal} / \mathrm{d}$ were withdrawn from the Carrizo-Wilcox aquifer, with use categories including about $0.60 \mathrm{Mgal} / \mathrm{d}$ for public supply, $0.16 \mathrm{Mgal} / \mathrm{d}$ for rice irrigation, $0.10 \mathrm{Mgal} / \mathrm{d}$ for general irrigation, and about $0.09 \mathrm{Mgal} / \mathrm{d}$ for rural domestic (Collier, 2018).

\section{Upland Terrace Aquifer}

The Upland terrace aquifer is present as a nearly continuous, slender, ring which borders the eastern, southern, and western parts of the Carrizo-Wilcox aquifer's extent in Red River Parish. Grain size within the terrace deposits generally becomes coarser 


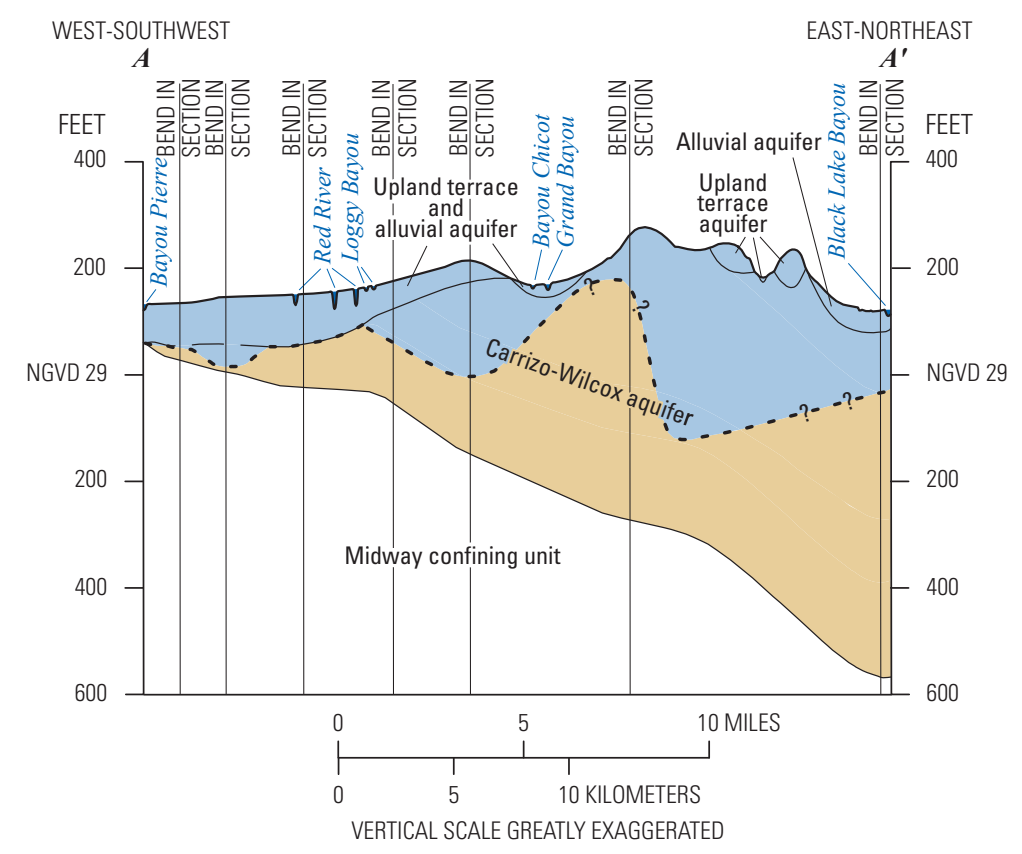

EXPLANATION

Hydrogeologic unit (modified from Smoot, 1988, 1989)

Aquifer containing freshwaterFreshwater contains a chloride concentration of 250 milligrams per liter or less

Aquifer containing saltwater

Confining unit

Hydrogeologic contact (modified from Smoot, 1989)-Separates hydrogeologic units. Dashed where approximately located

- - - Approximate freshwater/saltwater interface (modified from Smoot, 1989)—-Queried where uncertain

NGVD 29, National Geodetic Vertical Datum of 1929

Figure 3. Idealized west-to-east hydrogeologic section through Red River Parish, Louisiana, showing aquifer and confining unit intervals (individual sand and clay layers not shown). Modified from Newcome and Page (1962). Trace of section shown on figure 1.

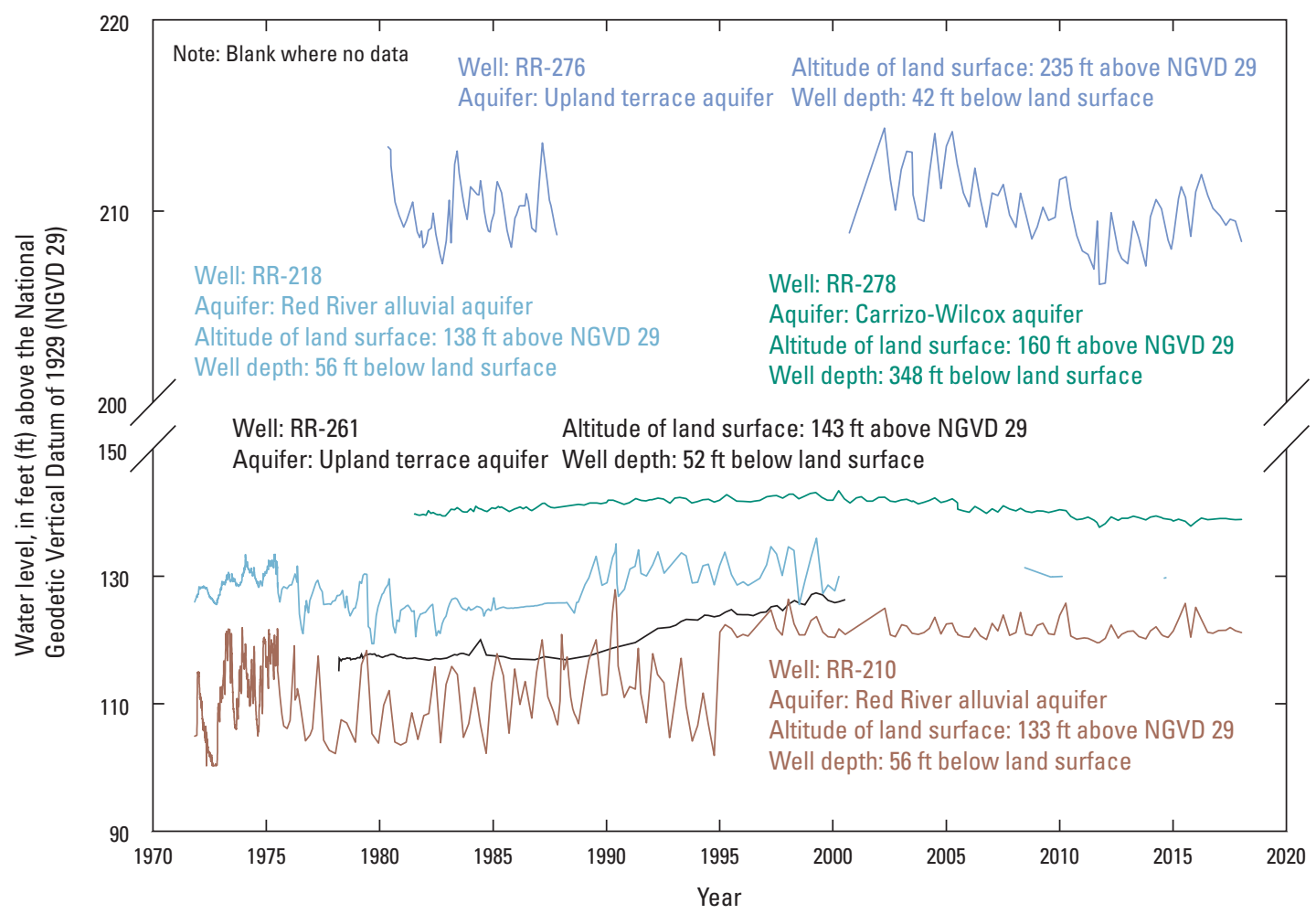

Figure 4. Water levels in wells RR-210 and RR-218 screened in the Red River alluvial aquifer, wells RR-261 and RR-276 screened in the Upland terrace aquifer, and well RR-278 screened in the Carrizo-Wilcox aquifer, Red River Parish, Louisiana (see figure 1 for well locations; U.S. Geological Survey, 2018).

with depth, ranging from clay and silt at the top to gravel towards the bottom. The primary source of recharge for the Upland terrace aquifer is the infiltration of precipitation, but recharge also occurs with leakage from underlying aquifers (Snider and Sanford, 1981; Stuart and others, 1994).
Water levels in RR-261 remained relatively unchanged from 1978 to about 1990. Water levels increased about $10 \mathrm{ft}$ during 19902000. Water levels in RR-276 have remained relatively constant at about $210 \mathrm{ft}$ during 1980-88 and again during 2000-17 (fig. 4). 
State well-registration records listed 122 active water wells screened in the Upland terrace aquifer in Red River Parish in 2017: 109 domestic, 5 public supply, 4 irrigation, and 4 industrial wells. Well depths ranged from 18 to $100 \mathrm{ft}$ below land surface, and reported yields ranged from 2 to $165 \mathrm{gal} / \mathrm{min}$ (Louisiana Department of Natural Resources, 2017). In 2014, about $0.35 \mathrm{Mgal} / \mathrm{d}$ were withdrawn from the Upland terrace aquifer, with use categories including $0.18 \mathrm{Mgal} / \mathrm{d}$ for general irrigation, $0.08 \mathrm{Mgal} / \mathrm{d}$ for rural domestic, $0.05 \mathrm{Mgal} / \mathrm{d}$ for rice irrigation, 0.02 for public supply, $0.01 \mathrm{Mgal} / \mathrm{d}$ for industry, and less than $0.01 \mathrm{Mgal} / \mathrm{d}$ for livestock (Collier, 2018).

\section{Groundwater Quality}

Groundwater samples were collected in Red River Parish from 60 wells screened in the Carrizo-Wilcox aquifer during 1955-2014, from 59 wells screened in the Red River alluvial aquifer during 1954-2013, and from 14 wells screened in the Upland terrace aquifer during 1941-78, as part of an ongoing, long-term program to monitor the State's groundwater resources (table 3). The results for the samples were generally within the U.S. Environmental Protection Agency's Secondary Maximum
Contaminant Levels ${ }^{2}$ (SMCLs) for color and for chloride and sulfate concentrations. Median values for $\mathrm{pH}$ exceeded the SMCLs in 64 percent of samples in the Upland terrace aquifer but were generally within the SMCL range for samples from the Carrizo-Wilcox and Red River alluvial aquifers. The median hardness values of $33.2 \mathrm{mg} / \mathrm{L}$ for the Carrizo-Wilcox aquifer and $22 \mathrm{mg} / \mathrm{L}$ for the Upland terrace aquifer were within the $\mathrm{soft}^{3}$ range, whereas the median hardness value of $480 \mathrm{mg} / \mathrm{L}$ for the Red River alluvial aquifer was in the very hard range. Manganese concentrations in the Carrizo-Wilcox and Upland terrace aquifers exceeded the SMCL of 50 micrograms per liter $(\mu \mathrm{g} / \mathrm{L})$ in about 30 percent of samples, and manganese concentrations in more than 99 percent of samples from the Red River alluvial aquifer exceeded the SMCL. Iron concentrations exceeded the SMCL of $300 \mu \mathrm{g} / \mathrm{L}$ in 47 percent of samples from the Carrizo-Wilcox aquifer,

${ }^{2}$ The SMCLs are Federal guidelines regarding cosmetic effects (such as tooth or skin discoloration), aesthetic effects (such as taste, odor, or color), or technical effects (such as damage to water equipment or reduced effectiveness of treatment for other contaminants) of potential constituents of drinking water. SMCLs were established as guidelines by the U.S. Environmental Protection Agency (2016).

${ }^{3}$ Hardness ranges, expressed as milligrams per liter of calcium carbonate, are as follows: 0-60, soft; 61-120, moderately hard; 121-180, hard; greater than 180, very hard (Hem, 1985).

Table 3. Summary of selected water-quality characteristics for groundwater from 59 wells screened in the Red River alluvial aquifer (1954-2013), 60 wells screened in the Carrizo-Wilcox aquifer (1955-2014), and 14 wells screened in the Upland terrace aquifer (1941-78) in Red River Parish, Louisiana (U.S. Geological Survey, 2018).

[Values are in milligrams per liter, except as noted. ${ }^{\circ} \mathrm{C}$, degrees Celsius; PCU, platinum cobalt units; $\mu \mathrm{S} / \mathrm{cm}$, microsiemens per centimeter; SU, standard unit; $\mathrm{CaCO}_{3}$, calcium carbonate; $\mu \mathrm{g} / \mathrm{L}$, micrograms per liter; NA, not applicable; <, less than; SMCL, Secondary Maximum Contaminant Level established by the U.S. Environmental Protection Agency (2016)]

\begin{tabular}{|c|c|c|c|c|c|c|c|c|c|c|}
\hline & $\begin{array}{l}\text { Temper- } \\
\text { ature } \\
\left({ }^{\circ} \mathrm{C}\right)\end{array}$ & $\begin{array}{l}\text { Color } \\
\text { (PCU) }\end{array}$ & $\begin{array}{c}\text { Specific } \\
\text { conductance, } \\
\text { field } \\
\left(\mu \mathrm{S} / \mathrm{cm} \text { at } 25^{\circ} \mathrm{C}\right)\end{array}$ & $\begin{array}{l}\text { pH, } \\
\text { field } \\
\text { (SU) }\end{array}$ & $\begin{array}{c}\text { Hard- } \\
\text { ness } \\
\text { (as } \\
\mathrm{CaCO}_{3} \text { ) }\end{array}$ & $\begin{array}{l}\text { Chloride, } \\
\text { filtered } \\
\text { (as CI) }\end{array}$ & $\begin{array}{l}\text { Sulfate, } \\
\text { filtered } \\
\text { (as } \mathrm{SO}_{4} \text { ) }\end{array}$ & $\begin{array}{c}\text { Iron, } \\
\text { filtered } \\
\text { ( } \mu \mathrm{g} / \mathrm{L} \text { as } \\
\text { Fe) }\end{array}$ & $\begin{array}{c}\text { Manganese, } \\
\text { filtered } \\
\text { ( } \mu \mathrm{g} / \mathrm{L} \text { as } \mathrm{Mn} \text { ) }\end{array}$ & $\begin{array}{l}\text { Dissolved } \\
\text { solids, } \\
\text { filtered }\end{array}$ \\
\hline \multicolumn{11}{|c|}{ Red River alluvial aquifer, 59 wells (1954-2013) } \\
\hline Median & 20.5 & 5 & 1,020 & 7.0 & 480 & 31 & 46 & 4,000 & 400 & 586 \\
\hline 10th percentile & 20.0 & 0 & 775 & 6.7 & 360 & 5.3 & 4 & 1,160 & 170 & 430 \\
\hline 90th percentile & 21.5 & 15 & 1,620 & 7.2 & 700 & 136 & 214 & 7,140 & 1,430 & 941 \\
\hline Number of samples & 269 & 165 & 388 & 461 & 599 & 625 & 537 & 507 & 508 & 189 \\
\hline $\begin{array}{c}\text { Percentage of samples that } \\
\text { do not exceed SMCLs }\end{array}$ & NA & 90 & NA & 98 & NA & 98 & 93 & 5 & $<1$ & 33 \\
\hline \multicolumn{11}{|c|}{ Carrizo-Wilcox aquifer, 60 wells (1955-2014) } \\
\hline Median & 20.6 & 10 & 415 & 7.3 & 33.2 & 21 & 1.6 & 250 & 30.6 & 277 \\
\hline 10th percentile & 19.8 & 0 & 179 & 6.7 & 6 & 5.9 & 0.2 & 45 & 10 & 162 \\
\hline 90th percentile & 22.1 & 41 & 950 & 8.2 & 124 & 195 & 14.2 & 1,900 & 115 & 493 \\
\hline Number of samples & 20 & 37 & 42 & 49 & 54 & 66 & 47 & 36 & 24 & 38 \\
\hline $\begin{array}{c}\text { Percentage of samples that } \\
\text { do not exceed SMCLs }\end{array}$ & NA & 67 & NA & 86 & NA & 91 & 100 & 53 & 71 & 89 \\
\hline \multicolumn{11}{|c|}{ Upland terrace aquifer, 14 wells (1941-78) } \\
\hline Median & 20.0 & 0 & 127 & 6.4 & 22 & 14 & 2.2 & 160 & 35 & 103 \\
\hline 10th percentile & 20.0 & 0 & 49.3 & 5.4 & 4.2 & 3.5 & 0.6 & 17 & 10 & 59 \\
\hline 90th percentile & 20.0 & 5 & 277 & 6.7 & 58.8 & 52 & 12.3 & 573 & 85 & 177 \\
\hline Number of samples & 2 & 11 & 12 & 14 & 15 & 17 & 13 & 8 & 6 & 10 \\
\hline $\begin{array}{l}\text { Percentage of samples } \\
\text { that do not exceed } \\
\text { SMCLs }\end{array}$ & NA & 100 & NA & 36 & NA & 100 & 100 & 75 & 67 & 100 \\
\hline SMCLs & NA & 15 & NA & $6.5-8.5$ & NA & 250 & 250 & 300 & 50 & 500 \\
\hline
\end{tabular}


95 percent of samples from the Red River alluvial aquifer, and 25 percent of samples from the Upland terrace aquifer.

\section{Surface-Water Resources}

Numerous surface-water resources in Red River Parish are present in four drainage subbasins which include the Black Lake Bayou subbasin (Hydrologic Unit Code [HUC] 11140209), the Middle Red-Coushatta subbasin (HUC 11140202), the Bayou Pierre subbasin (HUC 11140206), and the Loggy Bayou subbasin (HUC 11140203). In 2014, $1.54 \mathrm{Mgal} / \mathrm{d}$ were withdrawn from surfacewater sources including the John K. Kelly Grand Bayou Reservoir (0.37 Mgal/d), Red River (0.30 Mgal/d), Bayou Pierre (0.16 Mgal/d), and miscellaneous surface-water bodies $(0.70 \mathrm{Mgal} / \mathrm{d})($ table 1$)$. Uses for surface water included general irrigation $(0.64 \mathrm{Mgal} / \mathrm{d})$, industry $(0.37 \mathrm{Mgal} / \mathrm{d})$, public supply $(0.37 \mathrm{Mgal} / \mathrm{d})$, rice irrigation (0.08 Mgal/d), and livestock (0.06 Mgal/d) (table 2; Collier, 2018).

\section{Black Lake Bayou Subbasin}

The Black Lake Bayou subbasin covers the majority of eastern Red River Parish. Major streams in the subbasin in the parish include Grand Bayou, Black Lake Bayou, and Brushy Creek. The annual average streamflow during 1957-96 was 104 cubic feet per second $\left(\mathrm{ft}^{3} / \mathrm{s}\right)$ at Grand Bayou near Coushatta (USGS site number 07352800; fig. 1). During this same period, the highest monthly average streamflow was $222 \mathrm{ft}^{3} / \mathrm{s}$ in February, and the lowest was $7.5 \mathrm{ft}^{3} / \mathrm{s}$ in October (USGS, 2018).

\section{Bayou Pierre Subbasin}

The Bayou Pierre subbasin is present along the entire western border of Red River Parish and spans to the western edge of the Red River. Major streams in the subbasin in the parish include Bayou Pierre, which defines the western border of Red River Parish, and the Prairie River (fig. 1). The annual average streamflow during 19812018 was $971 \mathrm{ft}^{3} / \mathrm{s}$ at Bayou Pierre near Lake End (in Natchitoches Parish) (USGS site number 07351750; fig. 1). During this same period, the highest monthly average streamflow was $2,043 \mathrm{ft}^{3} / \mathrm{s}$ in February, and the lowest was $220 \mathrm{ft}^{3} / \mathrm{s}$ in August (USGS, 2018).

\section{Middle Red-Coushatta Subbasin}

The Middle Red-Coushatta subbasin covers the west-central part of Red River Parish and borders the Red River. Major streams in the subbasin in the parish include the Red River and Coushatta Bayou. The annual average streamflow during 1939-52 was $31,159 \mathrm{ft}^{3} / \mathrm{s}$ at the Red River at Coushatta (USGS site number 07350500; fig. 1). During this period, the highest monthly average streamflow was $62,113 \mathrm{ft}^{3} / \mathrm{s}$ in May, and the lowest was $9,943 \mathrm{ft}^{3} / \mathrm{s}$ during September (USGS, 2018).

Table 4. Summary of selected water-quality characteristics for samples from the Red River at Coushatta and the Grand Bayou near Coushatta, Louisiana (U.S. Geological Survey, 2018).

[Values are in milligrams per liter, except as noted. ${ }^{\circ} \mathrm{C}$, degrees Celsius; $\mathrm{PCU}$, platinum cobalt units; $\mu \mathrm{S} / \mathrm{cm}$, microsiemens per centimeter; $\mathrm{SU}$, standard unit; $\mathrm{CaCO}_{3}$, calcium carbonate; $\mu \mathrm{g} / \mathrm{L}$, micrograms per liter; <, less than; NA, not applicable; SMCL, Secondary Maximum Contaminant Level established by the U.S. Environmental Protection Agency (2016)]

\begin{tabular}{|c|c|c|c|c|c|c|c|c|c|c|c|c|}
\hline $\begin{array}{c}\text { Temp- } \\
\text { erature } \\
\left({ }^{\circ} \mathrm{C}\right)\end{array}$ & $\begin{array}{l}\text { Color } \\
\text { (PCU) }\end{array}$ & $\begin{array}{c}\text { Specific } \\
\text { conduc- } \\
\text { tance, } \\
\text { field } \\
(\mu \mathrm{S} / \mathrm{cm}\end{array}$ & $\begin{array}{c}\text { Dis- } \\
\text { solved } \\
\text { oxygen }\end{array}$ & $\begin{array}{l}\mathrm{pH}, \\
\text { field } \\
\text { (SU) }\end{array}$ & $\begin{array}{l}\text { Hard- } \\
\text { ness } \\
\text { (as } \\
\mathrm{CaCO}_{3} \text { ) }\end{array}$ & $\begin{array}{c}\text { Cal- } \\
\text { cium, } \\
\text { filtered } \\
\text { (as Ca) }\end{array}$ & $\begin{array}{c}\text { Mag- } \\
\text { nesium, } \\
\text { filtered } \\
\text { (as } \mathrm{Mg} \text { ) }\end{array}$ & $\begin{array}{l}\text { Chlo- } \\
\text { ride, } \\
\text { filtered } \\
\text { (as Cl) }\end{array}$ & $\begin{array}{l}\text { Sulfate, } \\
\text { filtered } \\
\text { (as } \mathrm{SO}_{4} \text { ) }\end{array}$ & $\begin{array}{c}\text { Iron, } \\
\text { filtered } \\
(\mu \mathrm{g} / \mathrm{L} \\
\text { as } \mathrm{Fe})\end{array}$ & $\begin{array}{c}\text { Man- } \\
\text { ganese, } \\
\text { filtered } \\
\text { ( } \mu \mathrm{g} / \mathrm{L} \text { as } \\
\mathrm{Mn} \text { ) }\end{array}$ & $\begin{array}{l}\text { Dis- } \\
\text { solved } \\
\text { solids, } \\
\text { filtered }\end{array}$ \\
\hline
\end{tabular}

\begin{tabular}{|c|c|c|c|c|c|c|c|c|c|c|c|c|c|}
\hline \multicolumn{14}{|c|}{ Red River at Coushatta (1969-2010) ${ }^{1}$} \\
\hline Median & 21 & 40 & 463 & 8.5 & 7.7 & 124 & 35 & 9 & 57 & 52 & 23 & 4 & 268 \\
\hline 10th percentile & 10 & 10 & 233 & 6.3 & 7.2 & 67 & 20 & 4 & 21 & 21 & 6 & 1 & 140 \\
\hline 90th percentile & 30 & 100 & 1,110 & 11.0 & 8.1 & 283 & 73 & 23 & 170 & 140 & 116 & 17 & 657 \\
\hline Number of samples & 372 & 330 & 374 & 359 & 366 & 314 & 314 & 317 & 324 & 321 & 94 & 84 & 357 \\
\hline $\begin{array}{l}\text { Percentage of } \\
\text { samples that } \\
\text { do not exceed } \\
\text { SMCLs }\end{array}$ & NA & 25 & NA & NA & 97 & NA & NA & NA & 100 & $<100$ & 99 & 100 & 79 \\
\hline
\end{tabular}

\begin{tabular}{|c|c|c|c|c|c|c|c|c|c|c|c|c|c|}
\hline \multicolumn{14}{|c|}{ Grand Bayou near Coushatta $(1955-86)^{2}$} \\
\hline Median & 18 & 70 & 140 & 6.7 & 6.3 & 29 & 6.5 & 2.8 & 18 & 7.4 & 495 & 2,150 & 98.5 \\
\hline 10th percentile & 6.9 & 36 & 88 & 2.6 & 5.8 & 18 & 4.1 & 1.7 & 8.2 & 1.3 & 222 & 103 & 76.6 \\
\hline 90th percentile & 27.8 & 100 & 192 & 9.4 & 6.9 & 39.9 & 10 & 4.8 & 37.6 & 13 & 915 & 9,030 & 139.8 \\
\hline Number of samples & 45 & 47 & 46 & 41 & 48 & 45 & 45 & 45 & 47 & 47 & 12 & 12 & 44 \\
\hline $\begin{array}{l}\text { Percentage of } \\
\text { samples that } \\
\text { do not exceed } \\
\text { SMCLs }\end{array}$ & NA & 2 & NA & NA & 44 & NA & NA & NA & 100 & 100 & 17 & 0 & 100 \\
\hline SMCLs & NA & 15 & NA & NA & $6.5-8.5$ & NA & NA & NA & 250 & 250 & 300 & 50 & 300 \\
\hline
\end{tabular}




\section{Loggy Bayou Subbasin}

The Loggy Bayou subbasin is present in the north-central part of Red River Parish, to the east of the Red River. Loggy Bayou is the only major stream present in the subbasin. The annual average streamflow during 1981-86 was 1,968 $\mathrm{ft}^{3} / \mathrm{s}$ at Loggy Bayou near East Point (USGS site number 07350020; fig. 1). During this same period, the highest monthly average streamflow was $4,466 \mathrm{ft}^{3} / \mathrm{s}$ in February, and the lowest was $270 \mathrm{ft}^{3} / \mathrm{s}$ in August (USGS, 2018).

\section{Surface-Water Quality}

Water samples were collected from the Red River at Coushatta (USGS site number 07350500) during 1969-2010 and Grand Bayou near Coushatta (USGS site number 07352800) during 1955-86 (fig. 1) as part of an ongoing program to monitor the State's surface-water resources. The results for the samples were generally within SMCLs for chloride and sulfate concentrations (table 4). The median value for $\mathrm{pH}$ and the median concentrations for iron and manganese were within or less than the SMCLs in samples from the Red River at Coushatta. Samples collected from Grand Bayou near Coushatta had $\mathrm{pH}$ values that were generally ( 56 percent) greater than the SMCL range for $\mathrm{pH}$ and had concentrations of iron ( 83 percent exceeded) and manganese (100 percent exceeded) that exceeded the SMCLs (table 4). The median hardness values of $124 \mathrm{mg} / \mathrm{L}$ in samples from the Red River and $29 \mathrm{mg} / \mathrm{L}$ in samples from Grand Bayou were within the hard range and soft range, respectively. Median values for dissolved-oxygen (DO) concentration were greater than $6 \mathrm{mg} / \mathrm{L}$ for both sites; $5 \mathrm{mg} / \mathrm{L}$ is considered the minimum DO value for a diverse population of fresh, warmwater biota, including sport fish (Louisiana Department of Environmental Quality, 2017). Median values for color were greater than the SMCL (15 platinum cobalt units) for both sites.

\section{References Cited}

Collier, A.L., 2018, Water withdrawals by source and category in Louisiana Parishes, 2014-2015: U.S. Geological Survey data release, https://doi. org/10.5066/F78051VM.

Collier, A.L., and Sargent, B.P., 2018, Water use in Louisiana, 2015: Louisiana Department of Transportation and Development Water Resources Special Report no. 18, 138 p.

Fendick, R.B., Jr., and Carter, K., 2015, Potentiometric surface, 2013, and water-level differences, 1991-2013, of the Carrizo-Wilcox aquifer in northwest Louisiana: U.S. Geological Survey Scientific Investigations Map 3311, 1 sheet. [Also available at https://pubs.usgs.gov/sim/3311/.]

Hem, J.D., 1985, Study and interpretation of the chemical characteristics of natural water (3d ed.): U.S. Geological Survey Water-Supply Paper 2254, 264 p., accessed February 20, 2013, at https://doi.org/10.3133/wsp2254.

Louisiana Department of Environmental Quality, 2017, Environmental Regulatory Code, Title 33, Part IX, Subpart 1: Baton Rouge, Louisiana Department of Environmental Quality, accessed September 10, 2019, at https://www.deq.louisiana.gov/assets/docs/Water/33v09201707WaterQuality.pdf.

Louisiana Department of Natural Resources, 2017, Strategic Online Natural Resources Information System (SONRIS): Louisiana Department of Natural Resources database, accessed June 12, 2017, at http://sonris.com/.

Newcome, R., Jr., and Page, L.V., 1962, Water resources of Red River Parish, Louisiana: U.S. Geological Survey Water-Supply Paper 1614, 133 p. [Also available at https://pubs.usgs.gov/wsp/1614/report.pdf.]

Ryals, G.N., 1982, Regional geohydrology of the northern Louisiana salt-dome basin; Part I, Conceptual model and data needs: U.S. Geological Survey Open-File Report 82-343, 23 p. [Also available at https://doi.org/10.3133/ ofr82343.]
Ryals, G.N., 1984, Regional geohydrology of the northern Louisiana salt-dome basin; Part II, Geohydrologic maps of the Tertiary aquifers and related confining layers: U.S. Geological Survey Water-Resources Investigations Report 83-4135, 6 p., 7 pls. [Also available at https://doi.org/10.3133/ wri834135.]

Seanor, R.C., and Smoot, C.W., 1995, Louisiana ground-water map no. 8; Potentiometric surface, 1991, of the Carrizo-Wilcox aquifer in northwestern Louisiana: U.S. Geological Survey Water-Resources Investigations Report 95-4176, 1 sheet. [Also available at https://doi.org/10.3133/wri954176.]

Smoot, C.W., 1988, Louisiana hydrologic atlas map no. 3-Altitude of the base of freshwater in Louisiana: U.S. Geological Survey Water-Resources Investigations Report 86-4314, 1 sheet, accessed November 2, 2011, at https://doi.org/10.3133/wri864314.

Smoot, C.W., 1989, Louisiana hydrologic atlas map no. 4-Geohydrologic sections of Louisiana: U.S. Geological Survey Water-Resources Investigations Report 87-4288, 1 sheet. [Also available at https://pubs.usgs. gov/wri/1987/4288/plate-1.pdf.]

Snider, J.L., and Sanford, T.H., Jr., 1981, Water resources of the terrace aquifer, central Louisiana: Louisiana Department of Transportation and Development, Office of Public Works Water Resources Technical Report no. $25,48 \mathrm{p}$.

Stuart, C.G., Knochenmus, D.D., and McGee, B.D., 1994, Guide to Louisiana's ground-water resources: U.S. Geological Survey WaterResources Investigations Report 94-4085, 60 p. [Also available at https:// doi.org/10.3133/wri944085.]

U.S. Environmental Protection Agency, 2016, Secondary Drinking Water Standards - Guidance for nuisance chemicals, accessed April 13, 2016, at https://www.epa.gov/dwstandardsregulations/secondary-drinking-waterstandards-guidance-nuisance-chemicals.

U.S. Geological Survey [USGS], 2017, U.S. Geological Survey Water Resources Cooperative Program-Louisiana Water Use Program, accessed December 14, 2017, at https://la.water.usgs.gov/WaterUse/default.asp.

U.S. Geological Survey [USGS], 2018, USGS water data for the Nation: U.S. Geological Survey National Water Information System database, accessed July 13, 2018, at https://waterdata.usgs.gov/nwis.

This fact sheet has been prepared by the U.S. Geological Survey (USGS), in cooperation with the Louisiana Department of Transportation and Development (DOTD), as part of a program to document water use, availability, and quality in the parishes of Louisiana. Information on the availability, past and current water use, use trends, and water quality from groundwater and surface-water sources in the parish is presented here. Previously published reports (see References Cited section) and data stored in the USGS National Water Information System (USGS, 2018) are the primary sources of the information presented here. Special thanks are given to Doug Taylor, Director, and Zahir "Bo" Bolourchi (retired), DOTD Cooperative Program with the USGS.

\section{By Angela L. Robinson and Vincent E. White}

\section{For additional information, contact:}

Director, USGS Lower Mississippi-Gulf Water Science Center 3535 S. Sherwood Forest Blvd., Suite 120

Baton Rouge, LA 70816

E-mail: gs-w-lmg_center_director@usgs.gov

Fax: (225) 298-5490

Telephone: (225) 298-5481

Home Page: https://www.usgs.gov/centers/lmg-water/ 